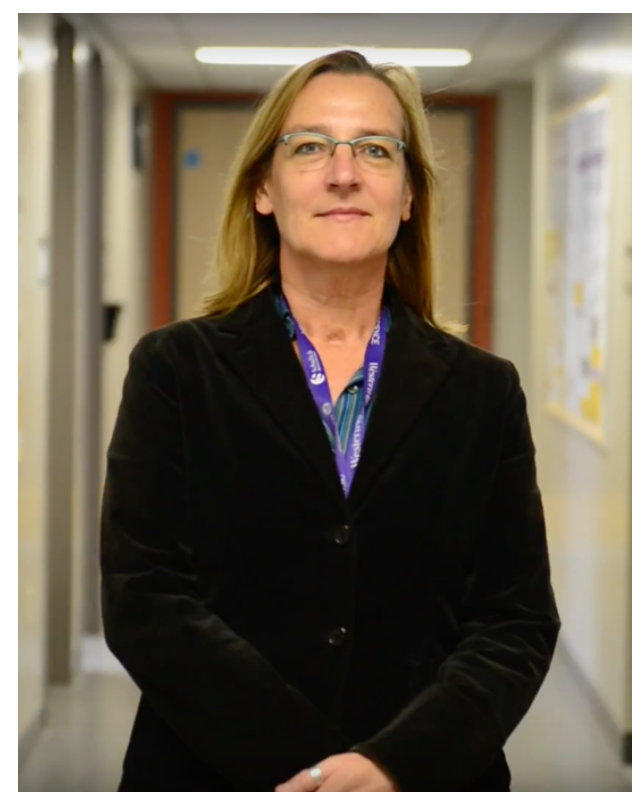

\title{
Western Faculty Profile: Dr. Susanne Schmid
} Anthony $\mathrm{Li}^{1}$

${ }^{1}$ Faculty of Science, Western University, London, Canada No conflicts of interest declared

\section{Background}

Dr. Susanne Schmid is the Associate Dean Research, Graduate \& Postdoctoral Studies at the Schulich School of Medicine \& Dentistry and an Associate Professor in the Department of Anatomy \& Cell Biology at Western University. Her research looks at early stages of sensory information processing and filtering, in particular habituation and prepulse inhibition. Anthony $\mathrm{Li}$, a member of the Academic Affairs Committee for WURJHNS, had the pleasure of interviewing Dr. Schmid to learn more about her career path and her research.

\section{Tell us about your career path - how did you end up at Western?}

I was born and raised in Germany, where I studied biology in a nice little medieval town. I further decided to pursue a doctorate at the University Eye Hospital, where I looked at synaptic plasticity and the development of the retina in a clinical setting. In Germany, I became an Assistant Professor; however, I felt that there was a lack of independence. When I received a 5year salary award, during which I did not have to teach, I did a guest professor stint at the University of Toronto in the department of Psychology. While there applied for various professorships in Canada. I was offered a position from Western, among others, and that's where I ended up! It's quite interesting how I moved from a biology and psychology background to my current position working within the Schulich School of Medicine \& Dentistry.

\section{Why focus on synaptic plasticity and the development of retina?}

As a student, I gave a presentation about patch clamp recording, which was a cool new technique at the time. I was set on doing that for my thesis, and there was only one person who I could do it with; she eventually became my PhD supervisor. It's quite random, but essentially the wish to learn this new technique led to my work on synaptic plasticity during retinal development!

\section{How did you first become exposed and interested in research?}

My first exposure to research - this is going to be a multitier answer. My parents had friends who were researchers, but one in particular - a biochemist - was an important role model to me as I grew up. She was one of the reasons I entered research. In addition, I went on a field trip to Ecuador where I conducted research in a rainforest during my undergraduate studies - I enjoyed that a lot. My other reason is a bit more unconventional I'm not sure if I should tell this story. I travelled to Brazil in an exchange and studied and lived there for a year. I enjoyed Brazil to the point that I was ready to drop out and just keep living there! Unsure of whether to stay in academia, I tested my limits and took the hardest thing that one could take in my program back then: a lab rotation course in neuroscience with a reputation of being extremely demanding and challenging. I decided to give it a shot and then see where to go from there. This course was full of mini research projects with four projects in a term. I worked twelve sixteen hours a day, seven days a week, and I absolutely loved it. I loved the course, and that is when it really hit me that I wanted to do research.

\section{Is there any element of your life path you would change?}

No, not at all. My path was never straight forward - a lot of things were coincidences, total coincidences. I didn't know from the get go that I was going to end up in neuroscience research. The fact that I ended up in neuroscience, doing both research and being a professor, was a combination of coincidences, having great role models, and a bit of trial and error. 


\section{How many new projects could you see yourself taking on?}

I don't think there is an end in sight. It's the same with all scientific research: the more research you do, the more new questions arise. To expand, I started on one field as a biologist looking at the mechanism of sensory filtering, but now I am looking through a medical lens and seeing how the mechanism is disrupted and looking at different neurodevelopmental disorders. We really want to go from cellular molecular levels to neurocircuitry to neurodevelopment to behavioural consequences, and then eventually to how we can modify and intervene to compensate for any disruptions. This is more than I can do in my lifetime!

\section{What animals do you prefer to work with?}

I mostly work with rats. There are some things, such as genetic models, that can't be done on rats and so I have also used mice in the past. I have also collaborated on projects with monkey and human subjects. Rats are a great model with some limitations. As long as people are aware of the limitations that exist, one can choose the best model for the type of question you ask.

Research allows for major discoveries to be made, but certain projects take significantly longer than others. Have you ever been discouraged in the past?

I think if any researcher said no to this question, they would probably not be a researcher - that's how scientific research works. Everything seems to be so straight forward when you start the project, but as soon as you begin many things don't happen the way they should. This is what makes science interesting! Students often get upset when things don't go the way they should, but they need to learn that this is normal, this is science. I think maybe $10-20 \%$ of things work out the way you plan for them to occur, and that's the exciting part.

\section{What would you recommend to students wishing to pursue a path in research?}

Students are often very interested in "diseases" and "disorders," and I frequently hear the phrase "I am interested in neurodegenerative diseases" or things along that sort. However, on a day to day basis, what is important is the techniques that one works with and the team that one is in. I hope for students to focus more on the techniques and approaches that they want to learn and master, since that is what they will be doing on a daily basis. They should look for a good supervisor rather than work on an "appealing sounding" project that is somewhat related to a disease or disorder. What we ultimately all do is basic research - you can always link it to a disease, but in your daily work, this linkage does not play a big role. Your techniques, your team, and your supervisor define your work. As a student, you have a rare opportunity where you are able to pick your colleagues and your boss, and so you need to pick wisely. Pay more attention to these things than on the big picture.

\section{What is your favourite and least favourite part about investing time into research?}

My least favourite part is definitely the management. I essentially run a business where I handle human resources, revenues, and expenses. This is something that I have not learned and I dread this administrative type of work. Grant applications can be particularly tiresome. Although sometimes I enjoy writing them, a lot of time has to be invested. In fact, sometimes I spend $80 \%$ of my time writing grants. What I most enjoy is sitting with my graduate students and trainees to talk about their projects. The best part is getting excited about results, especially unexpected ones, and trying to wrap our heads around the data. Attempting to interpret results and thinking about next steps is fun, and of course when a paper is published, that is a very rewarding moment.

\section{Is there anything that you want people to know?}

One thing that's been impactful throughout my career is the notion of role models. Role models are very important, and in particular for me, female role models. Scientific research is still a very male-dominated field, and this creates an unconscious bias among (not only) students. There needs to be more female role models. More female researchers would change people's perceptions and provide more female role models for the female students, who make up a majority of the student body.

\section{To Learn more on Dr. Schmid's lab and research, please visit her website at:}

http://www.schulich.uwo.ca/anatomy/people/bios/faculty/schmid_ susanne.html 